\title{
The Famished Road: Ben Okri's Family Romance?
}

\section{Mélanie Joseph-Vilain}

\section{(2) OpenEdition}

Journals

Electronic version

URL: https://journals.openedition.org/ces/5358

DOI: $10.4000 /$ ces.5358

ISSN: 2534-6695

\section{Publisher}

SEPC (Société d'études des pays du Commonwealth)

\section{Printed version}

Date of publication: 1 April 2013

Number of pages: $67-78$

ISSN: 2270-0633

\section{Electronic reference}

Mélanie Joseph-Vilain, "The Famished Road: Ben Okri's Family Romance?", Commonwealth Essays and Studies [Online], 35.2 | 2013, Online since 17 April 2021, connection on 23 July 2021. URL: http:// journals.openedition.org/ces/5358; DOl: https://doi.org/10.4000/ces.5358

\section{(c) (i) (3) $\Theta$}

Commonwealth Essays and Studies is licensed under a Licence Creative Commons Attribution - Pas d'Utilisation Commerciale - Pas de Modification 4.0 International. 


\section{The Famished Road: Ben Okri's Family Romance?}

This article suggests that by breaking the cycle of the abiku, Okri inserts Azaro into a lineage that turns him into a storyteller. It explores the nature of parent-child relationships in the novel from this perspective, using the concept of family romance to show how the association of family with storytelling reverberates in Okri's writing.

Ben Okri's The Famished Road famously starts in the spirit world, a world in which Azaro and his fellow abiku enjoy a timeless mirth, far away from humanity's limitations and grievances. In this secluded world, ruled by a red-bearded king, "there was much feasting, playing, and sorrowing" (3). The "sorrowing," Azaro explains, occurs after visiting the world of the Living, where the spirit children encountered "love they had left behind" and "suffering they had not redeemed" (3). Because going to the world of the Living and back entails so much "suffering," the spirit children, we learn, are reluctant to leave their companions:

There was not one amongst us who looked forward to being born. We disliked the rigours of existence, the unfulfilled longings, the enshrined injustices of the world, the labyrinths of love, the ignorance of parents, the fact of dying, and the amazing indifference of the Living in the midst of the simple beauties of the universe. We feared the heartlessness of human beings, all of whom are born blind, few of whom ever learn to see. (3)

The litany of evils to be found in the world of the Living, with an accumulation of negative terms connected both to feelings or the lack thereof ("longings," "love," "indifference") and to factual, if vague, elements ("rigours," "injustices," "labyrinths," "dying"), justifies the reluctance of the spirit children to leave the protected sphere of their own world. And yet, in spite of the happiness that characterizes the world of the Unborn, Azaro chooses to stay among the Living, thus breaking the cycle of endless births and deaths that characterizes the abiku. In so doing, he dissociates himself from the community of spirit children ("us") to become an individual - hence the shift to the first person singular in the final paragraph of the first chapter of Book One:

I was born not just because I had conceived a notion to stay, but because in between my coming and going the great cycles of time had finally tightened around my neck. I prayed for laughter, a life without hunger. I was answered with paradoxes. It remains an enigma how it came to be that I was born smiling. (7)

Quayson observes that situating Azaro's point of view is problematic; this leads him to remark on Azaro's capacity to "speak as himself as well as a communal intuition in which he is vitally implicated by being (in the sense of living the essence of) abiku" (Strategic Transformations 127). This implicitly raises, in addition to the question of the narrative stance and of Azaro's voice, the issue of individuality and individual identity. This article will endeavour to explore this paradox: Azaro, who as an abiku remains attached to the spirit world in many ways, also partly dissociates himself from it and becomes anchored in "real" twentieth-century Nigeria. It will be argued that combining the two positions, that is, articulating the spirit world with the "real" world - an aspect of the novel that has already been dealt with extensively by previous criticism and has 
often been analyzed as a form of magical realism - is made possible by Azaro's insertion into a family and a genealogy. The demonstration will rely on an exploration of the notion of repetition, which connects the abiku's cyclical world with the linear world of the Living.

The choice of the abiku as a central character and narrator places Okri within a tradition, as he himself pointed out at a conference held in Lyon on October 18th 2012, during which he described the abiku as "a resonant entry into a whole tradition and a whole way of seeing" (Guignery Homelands, 25) - a clear emphasis on the collective dimension of the abiku. By choosing to remain among the Living, Quayson argues, Azaro leaves the "mythical" time of the spirit world for "a more time-bound scheme of temporality." But this "time-bound scheme of temporality" retains an "iterative" dimension: the events described in Chapter Two are "a tissue of the repeated and habitual," (Strategic Transformations 127) and, more generally, "a homogeneous sense of a-temporality, relieved only by the vaguest time indices, is spread throughout the narrative" (129). Fernandez Vasquez similarly writes that "whatever the simile" used to describe the logic of The Famished Road, "we always come across a cyclical rhythm, with an underlying symmetry that might not be perceived at first sight" (99). The reader is therefore faced with a paradox: the real world in which Azaro chooses to stay seems as cyclical, repetitive and mythical as the world of the Unborn. Part of the repetitive quality of "real" time is linked to the vagueness of time indices (Quayson Strategic Transformations, 128) and to the prism of the child's perception. It may also be argued that the constant overlapping of the spirit world with the real world adds to the confusion and reinforces the feeling of similitude between the two, as suggested for instance by the fact that even the mundane activities of the inhabitants of the compound often consist in "the repetition of the same" (Guignery Seeing, 71).

However, the notion of cyclicality would merely imply a recurrence of identical events or notions, which is not the case in The Famished Road, if only because it is a narrative. As Maggi Phillips reminds us in her analysis of "the methods by which Okri 'unfixes' his narrative into a river-like storytelling," narratives are inescapably linear:

Narratives, spoken or written, are forcibly linear. Storylines and ideas unfold successively despite attempts by mythmakers and storytellers since time immemorial to diverge from or embellish the linear structure, or to evolve it into other geometrical patterns which the eye can see and the imagination can grasp. (167)

Vanessa Guignery, on the other hand, argues that "by choosing to stay alive, Azaro breaks the cycle and gives a linearity to the road of his life," (Seeing 43) which seems in contradiction with Quayson's insistence on the repetitive and a-temporal quality of the narrative. Okri himself seems to solve the apparent contradiction between perceptions of time in The Famished Road as either cyclical or inescapably linear by resorting to the image of the spiral rather than the cycle: "I've been accused by certain ruler-headed readers of repetition. I often wanted to sit them down with a nice glass of wine and say 'What you see as repetition is not really repetition, it's a spiral'. It appears to go back to the same place, but it doesn't." He explains that to solve the opposition between what he calls "the linear time of history and the cyclical time of myth" he has tried to create a third time that "runs right through the centre of that": Azaro's time, which he describes as "vertical." He even refers to time as "one of the unmentioned characters of the book" (Guignery Homelands, 26). To justify this vertical conception of time, Okri argues 
that The Famished Road is "a meditation on consciousness as it is modulated by tradition and history" (Guignery Homelands, 25).

It is striking to note that the solution Okri proposes to solve the apparent contradiction between mythical and historical time relies on Azaro and on the concept of consciousness. Since consciousness implies individuality, the key to reconciling cyclical and linear temporalities is the individual. The Famished Road has been described as a "postcolonial Bildungsroman" in which Azaro "grows from childhood to adulthood by developing a greater social awareness" (Fernandez Vasquez 93). The Famished Road is then, among other things, a narrative of the emergence of an individual and the building up of a personality. This confirms J. C. Hawley's notion that Okri deals with the "politics of the interior" (34): the emphasis is not only on collective politics, but also on the individual - even if the question of Nigerian politics is far from being evacuated from the narrative (Guignery Seeing, 143).

The emergence of Azaro's individual consciousness is made possible only by his insertion into a group; more specifically, the Bildungsroman dimension seems to result from Azaro's integration into a family and, through this, a genealogy. The nuclear family, symbolized in the novel by Dad's three-legged chair, is indeed the locus where Azaro's identity is regularly reaffirmed and consolidated. Surprisingly, Dad and Mum both share with Azaro characteristics that normally belong to the abiku, in particular the latter's ability to die and be reborn repeatedly. The most obvious example is Dad: "Interestingly enough, Dad himself is associated with the figure of Lazarus as he symbolically dies three times in fights and each time is reborn, thus taking on some of the characteristics of the abiku itself" (Guignery Seeing, 80). The similarity with the abiku is reinforced in The Famished Road by the suggestion that Dad looks like "the biggest newborn baby in the world" (410) when he emerges from one of his symbolical deaths. Mum also nearly dies in the thirteenth chapter of Book One: "When she didn't move, didn't breathe, I ran all the way to Madame Koto's bar to tell her that my mother was dying" (66). During her near-death experience, Mum meets Azaro, and when waking up she asks him to explain his presence there; Azaro denies being in her vision and cannot explain why he was "walking upside-down" or had "little legs" on his head (69), but Mum's visions prove she has been, even briefly, to the spirit world. These experiences of Mum's and Dad's mirror Azaro's own near-death experience after Dad's flogging following which, Renato Oliva points out, "his hallucinations cease for a time, and when they resume they have partly changed character. Now they are concerned with his ancestors, or with African history" (179). This shift in Azaro's hallucinations seems to confirm that the boy's near-death and rebirth experience has severed part of his connection with the spirit world and reinforced his connection with Mum and Dad, who anchor him in the real world.

Interestingly, even if this capacity to be reborn in one life points to the abiku-ness of all lives, as suggested by Dad's interrogation "How many times is a man reborn in one life?" (414), and therefore could seemingly be extended to all mankind, ${ }^{1}$ it does create a specific identity for Azaro's family, especially as Azaro, Mum and Dad are the only characters in The Famished Road who go through this type of cyclical rebirth experience, an experience connected to the notion of origin in Okri's mind: "within each beginning

1. Hence Okri's interrogation in an interview with Jane Wilkinson: "Isn't it possible that we are all abikus?" (Wilkinson 84) 
is an ending, and within each ending is a beginning" (Wilkinson 83). Mum's and Dad's deaths and rebirths might account for Azaro's choice to remain with them: they can be read as symbolically abiku parents for an abiku child.

Azaro does admit that his parents, in particular Mum, are the reason why he stayed, but does not explicitly link their abiku-ness to his own; instead, he repeatedly asserts that he chose to stay because of his mother's face: "But I sometimes think it was a face that made me want to stay. I wanted to make happy the bruised face of the woman who would become my mother" (6). Later on in the novel, it is when this beloved face takes on the "bizarre immobility of a mask" that Azaro, confronted with his mother's misery, suddenly feels overwhelmed by grief:

Suddenly I had a vision of her death. It came and went so fast and it left me perplexed. I remembered her face when she nearly died just after my homecoming. I remembered that it was because of her bruised face that I had chosen to live, to stay, in the confines of this world, and to break my pacts with my spirit companions. One of the many promises I made before birth was that I would make her happy. I had chosen to stay, now she wanted to die. (266)

It is worth noting that at such a critical moment the two key events Azaro remembers are his birth, and Mum's near-death experience, which confirms that the latter bonds them together as strongly as the moment of his birth. Immediately after the extreme grief he feels for his mother, Azaro himself experiences a near-death that echoes his mother's: "My heart stopped beating. I froze, became rigid, didn't breathe, my mouth open, eyes wide. Darkness rushed over me, a powerful wind from the forest. The darkness extinguished my consciousness" (266). Significantly, Azaro's third eye opens precisely in reaction to Mum's grief and to his own subsequent feelings of inadequacy, which shows how strong the connection between them is. ${ }^{2}$ It is so strong, in fact, that Mum's real name is never mentioned in the novel: she is identified only as Azaro's mother, just as Dad is identified only as his father (Guignery Seeing, 144). Both parents thus acquire an archetypal dimension, fulfilling first and foremost the functions of father and mother. This may partly account for Dad's "heroic, mythic and titanic dimension," (Guignery Seeing, 154) which causes Azaro to see him, repeatedly, as a figure "like a giant in fairy tales," (Okri 34) "the guardian giant who led me into the discoveries of our new world," (41) speaking "with the voice of a sad giant," (42) a figure larger than life in the eyes of his son. However, their identification as only "Mum" and "Dad" does not imply any kind of perfection on their part. Both characters have flaws. Dad, in particular, emerges as a rather ambivalent paternal figure, obsessed as he is with boxing and with his own political ideals, which prevent him from seeing the sacrifices made by Mum and Azaro for his sake, in particular when they choose to go hungry so that he can eat more and train for boxing matches. To the reader, Dad's apparent negligence and imperfection contribute to his plausibility as a man and as a father figure. Both he and Mum know they root Azaro in the real world, as suggested by the following exchange:

2. "And Mum, underneath it all and surrounding it all" (Wilkinson 85). 
"If a spirit calls you," Mum said, "don't go, you hear? Think of us. Think of your father who suffers every day to feed us. And think of me who carried you in my womb for more than nine months and who walks all the streets because of you."

"Yes, think of us," Dad added. I nodded. (352)

No wonder Azaro's "terrible hunger for a destination" after escaping from the men who kidnapped him in Madame Koto's bar and took him away in a bag is described as first and foremost a hunger for "Mum's face, and Dad's smells" (133).

The connection between Azaro and his parents establishes itself through mundane gestures, the sharing of meals, the sharing of the small space of their home, but also through storytelling. Mum is a storyteller, who often tells tales to her son: the story about the stomach (94), "a story about white people," (325) "the story of the blue sunglasses," (552) which contains embedded stories in it since the man with the blue sunglasses tells Mum stories as well. The stories Mum tells Azaro usually have a didactic purpose. So do most of Dad's stories. Telling Azaro the story of his grandfather, for instance, enables Dad to assert Azaro's belonging to his family and to insert him into a genealogy:

"Your grandfather is completely blind now. He is the head-priest of our shrine, Priest of the God of Roads. Anyone who wants a special sacrifice for their journeys, undertakings, births, funerals, whatever, goes to him. All human beings travel the same road."

He paused. Then continued:

"I was supposed to succeed him as priest but the elders of the village said: Your son is a fighter. How can a fighter be the Priest of Roads? The god has chosen a successor outside your family. But who knows the future?' Your grandfather was very disappointed about this. He is blind now and he wears dark glasses and wanders through the village and the world without any walking stick or any help. Our old people are very powerful in spirit. They have all kinds of powers." (83-4)

Through his words, Dad provides Azaro with a lineage and suggests that the boy can be proud of it. Because of Dad's political preoccupations, his stories often have a "visionary and shamanic quality" (Guignery Seeing, 123) particularly perceptible in the general statements he utters about life, death, or hunger: just after telling Azaro about his grandfather, for instance, he states that "[t]he only power poor people have is their hunger" (84).

In The Famished Road storytelling counteracts "the doom of repetition," (Guignery Seeing, 132) that is, the dreadful events that are repeated again and again throughout the novel: political violence and riots, among others. The "stories of recurrence told down through generations" (Okri 208) counterbalance the violence of "a night replaying its corrosive recurrence on the road of our lives" (211) and "the wind of recurrence" (215). Similarly, Azaro remembers his parents telling stories to him while outside "the wind of recurrence blew gently over the earth" (215). Such "stories of recurrence" point to the safety of the nuclear family and to a form of filiation, and affiliation, through storytelling. The healing, soothing power of storytelling and its connection with filiation can be detected as well in the way Dad brings Azaro back to life after his hunger strike, by telling him stories about ancestors and about gods, providing him with roots to anchor him in the real world:

Kneeling by the bed, he sang wonderful tunes into my ears. He told me stories in songs about our ancestors who had left their original land and made a strange place their home; 
about grandfather who fought a great spirit of the forest for seven days and was made the Priest of the Shrine of Roads; about gods who divided the universe between the land of spirits, the land of humans, and the infinite regions of heavenly beings, and who gave in all realms a special homeland for the brave. (389)

Mum also tells him about his ancestors when watching over Dad as he lies in bed at the end of the novel (549-50).

The connecting effect of storytelling is visible as well when the family members are reunited after Azaro's stay in the police officer's "house of ghosts" and almost immediately tell one another what happened to them. While Azaro washes himself Mum stays outside the bathroom and tells him "all that had happened since the night of the riots" (35). Azaro, in turn, is asked to tell his own story, and the storytelling is a shared moment that re-establishes the connection that had been briefly severed:

I began telling them when the lights changed in the room and mighty hands lifted me up and put me on the bed. I saw Dad smiling beneath his bloodied bandage. Mum shifted the chair and centre table, spread out a mat and slept on the floor. Dad sat on his wooden chair, smoked peacefully, and lit a mosquito coil. I listened to him talking to the silent room, asking riddles that only the dead can answer. (39)

Azaro's storytelling is interrupted because of his exhaustion, but the bond between him and his parents has been re-established, and harmony prevails. Like the moments when Azaro listens to the fictional stories told by his parents, which "are a special time in family life, bonding father, mother and son in a triangular relationship epitomized by the three-legged chair," (Guignery Seeing, 123) this passage illustrates the bonding quality of storytelling within the family. Interestingly, the final words of the paragraph, "asking riddles that only the dead can answer," which describes Dad's talking, is a variation on the sentence Dad himself tells Azaro when coming back from killing the boar: "Life is full of riddles that only the dead can answer," (48) a statement that is echoed and transformed throughout the novel. Quayson explains that such sentences can be attributed to a kind of "communal narrator" sharing the same world-view and culture (Strategic Transformations 126), or, Guignery argues, "it could be an echo of the voice of his own father as some of the statements uttered by the narrator were previously pronounced by Dad": "The narrator thus seems to be mature enough not only to repeat Dad's proverb, but also to modify it and thus appropriate it at key moments in the progression of the book (significantly at the beginning or end of sections) maybe leading him to wonder: "Was I being reborn in my father?"' (Seeing 88). Quayson uses these examples to underline the discrepancy between the two Azaros: the narrator, who can show a maturity unlikely in a child, even an abiku one, and the character, who is, most of the time, "passive and vulnerable," (Guignery Seeing, 82) and "is a victim of the circumstances of his abiku-ness and lives in a permanent state of fluid liminality" (Quayson "Protocols of Representation," 147).

If such statements are indeed of communal origin, it can be argued that most of the time they echo or transform Dad's shamanic statements. They can therefore be interpreted as a form of ventriloquism, or, in a more positive way, as a form of familial transmission and inheritance. As a narrator, and as an individual, Azaro is positively haunted by his father's words. This form of echo therefore points to an identity that is at the crossroads of the individual and of the collective, the family being, precisely, the locus where this connection is achieved. 
From this perspective, The Famished Road can be described as an avatar of the family romance, which is Freud's phrase for the stories children tell themselves to come to terms with their filiation and with the Oedipus complex. The need to tell such stories arises from a tension between the "paternal" and the "maternal":

What is important here is not the mere distinction between the presence of "the father"
or "the mother," or "the maternal" and "the paternal" in a text or a novel. What should
be interpreted is the tension between these two factors, the inevitable conflict that arises
from them, and also the harmony that they may create. This conflict interferes with the
polarity of desire and resistance from which the unconscious originates. For, in our fan-
tasies, mother and father are both objects of desire as well as of rejection. We all expe-
rience this play of regression and progression and cope more or less harmoniously with
these tensions. The literary process and the transference it implies may contribute to that
experience and our understanding of it. (Hilenaar 5)

It might seem surprising to use this concept for an abiku, who, by definition, escapes the condition of ordinary children and the need to overcome the Oedipus complex. However, in light of the part played by storytelling in Azaro's bond with Mum and Dad, the family romance provides a key to understanding some of Azaro's attitudes. In Freud's conception of the family romance, there are two stages in the child's development: an early stage makes the child imagine that he is a foundling. When the child later realizes that "mater est certissima," he then re-invents himself as a bastard. In her history of the novel, Marthe Robert uses Freud's concept of the family romance to distinguish between two types of writers: the "Foundlings" and the "Bastards," and she argues that realism is mostly linked to the bastards while departure from realism links the writer to the foundling category. Even if this analysis seems reductive, and even if, as André Jarry has pointed out, Robert's analysis fails to separate the level of the writer from that of the characters, ${ }^{3}$ this distinction between the bastard and the foundling in terms of realism or, on the contrary, dream and fantasy, can help us understand why Okri combines African and Western influences in his novel. This combination might be a trace of Azaro's double lineage; indeed, almost all articles or books analyzing Okri's novel pay attention to his use of what has been labelled, against Okri's own will, "magical realism," that is, the unproblematic combination of realistic features and elements from the world of spirits, and, more generally, "the non-disjunction of contradictory elements (myth/history, naturalia/mirabilia) - not either/or, but both/and" (Linguanti 6). Oliva, for instance, describes Azaro's world-view as illustrating a "magical conception of the world," (190) informed by magical thinking which "knows nothing of the principle of contradiction" (191). This explains why "Okri abolishes the neat polarities and linear movement - of the past and future, of the modern world and the old - in the very process of their erection" (Cooper 68).

Indeed, as an abiku child, Azaro is both the son of his parents, Mum and Dad, and of the spirit world, embodied by the shape-shifting figure of the great King with "eyes of greenish sapphire" (3). Azaro's double lineage, mythical and real, is presented as unproblematic in the novel. He is both a spirit child and the son of his parents - or neither, since he chooses to sever the connection with his companions and to remain with Mum and Dad, who are, and are not, his parents. Most critics, and Okri himself, suggest that

3. Jarry observes that in her demonstration Marthe Robert does not separate "the "writing' writer" from "the writer in the events of his life," that is, "the writer in the text" and "the writer outside the text" (155, my translation). He adds that she keeps on shifting from the writer to his characters, thus blurring the clarity of her argument (156). 
the coexistence of the spirit and the real world is part of the African world-view. However, it is striking to note that the great Spirit King's words to Azaro before his birth are: "This life of yours will be full of riddles," (6) a sentence strikingly similar to Dad's own statements about life. It might be argued that the King, an imaginary figure in keeping with the imaginary father figure in family romances, who is generally "of noble lineage, or at least of a higher social class than the real parents," (Mijolla-Mellor 548) has been imagined and shaped by Azaro and is a double of Dad. But such an interpretation, of course, would be reductive as it would only take a Western point of view into account, while there is little doubt that for Okri the King is as real as Mum and Dad.

Azaro's specificity lies, as Guignery explains, in the notion of choice: "By choosing to break the cycle of life and death, Azaro subverts the very essence of the abiku and departs from the (more or less) traditional figure portrayed in West African mythology and Nigerian literature" (Seeing 73, my emphasis). By choosing to remain with Mum and Dad, Azaro re-invents himself. What is also subverted is the very notion of family romance, which normally implies inventing mythical genitors for oneself to replace an unsatisfactory lineage (Bellemin-Noël 38). In Azaro's case, the abiku child reinvents himself as an ordinary boy, a striking inversion of the Freudian conception of family romance - unless, of course, Azaro is no abiku at all, and his spirit-child condition is the family romance he invents for himself. The solution probably lies in a combination of the two. As previously stated, as an abiku child, Azaro both is and is not Dad's and Mum's son, and the apparent contradiction is unproblematic in his eyes. What is more, even if the pattern seems to be reversed, Azaro's self-reinvention as an ordinary boy fulfils the same function as the classic family romance: it helps him come to terms with his origins and appropriate his spirit-child identity.

The Famished Road can thus be read as Azaro's "family romance." But it can also be interpreted as Ben Okri's family romance because of its autobiographical dimension: a number of details were inspired by Okri's own experience as a child in Nigeria, and Azaro's parents owe much to Okri's own parents - especially regarding the inspirational nature of their storytelling, as Okri explained in an interview with Hilary Wilce: "My mother gave me the story-telling spirit. Form is Dad, narrative is Mum. Anything she wanted to tell me, any lessons about life she wanted to give me, she knew if she told it to me straight I would resist it, so she always told me a story with a serious point hidden in it" (7). Similarly, the character of Dad is partly modelled on Okri's Dad, who "introduced him to the classical tradition and Western canonical works" (Guignery Seeing, 121) - a description that is reflected in Dad's choice of books in The Famished Road:

Dad began to spend a lot of the money he had won in buying books. He couldn't read but he bought them. I had to read them to him. He bought books on philosophy, politics, anatomy, science, astrology, Chinese medicine. He bought the Greek and Roman classics. He became fascinated by the Bible. Books on the cabbala intrigued him. He fell in love with the stories of the Arabian Nights. He listened with eyes shut to the strange words of classical Spanish love poetry and retellings of the lives of Shaka the Zulu and Sundiata the Great. He insisted that I read something to him all the time. (468)

Azaro is somewhat baffled by Dad's eclecticism, and because of his young age he does not really understand what he reads: "Most of what I read made no sense to me" (4689). The one who seems to have actually read and digested Dad's books is Okri, who defines himself as "a crossroads person, a child of intersection" as in him "Africa and Eu- 
rope meet," (Hattersley 6) and who explains that he started consciously writing thanks to the books his father brought from his law studies in London: "My father returned from his law studies in London with a library of Western classics from Dickens to Mark Twain, the Greeks, the Romans, Austen, English essays, books he didn't actually have the time to read. Those books were my beginnings" (Wilkinson 77).

This statement confirms the idea that The Famished Road, which pays a tribute to all these hybrid influences through the characters of Azaro and Dad, can be read as Okri's literary family romance, especially as he insists on the idea that they did not "inspire" him but "gave [him his] beginnings" (Wilkinson 77) because "reading prepares you for writing" (78). Okri's readings - taken in a broad sense since they include the stories his mother told him - were diverse and hybrid, and formed a unique combination:

My earliest readings were of folktales and myths, Greek myths, German myths, Roman myths, African myths, African legends. And my mother told me stories. All of them were intermingled. I didn't separate one thing from the other. Aladdin was as African to me as Ananse. Odysseus was just another variation of the tortoise myth. (Wilkinson 78)

In a sense, with The Famished Road Okri reinvents himself as an abiku child and thus becomes an abiku writer. He reconciles Africa and Europe by combining orature and myth, embodied in the novel's spirit world, on the one hand, and linearity and historicity on the other. The repetitive aspect of his prose, far from being a mere oral feature, might be interpreted as Okri's way of weaving these influences together and escaping the labels that irritate him so much. When asked if he thought of himself as an African writer, he answered that he did not think of literature in such terms:

There are African writers who are German. There are English writers who are French and French writers who are English. Perhaps we should look for other ways of categorizing writers rather than their nations. I think their sympathies, their affinities, their literary families, their prophecies, their rebellions, their antipathies might be more fruitful. There are diagonal lines across literature. I dream of the day when literature will be talked about not only in terms of nations or periods but also in terms of magical affinities, contrasts and argument. (Guignery Homelands, 28-9)

Okri also explains that he wrote The Famished Road thanks to what he calls "echo writing," that is, the capacity of the eye to see a word here and a word there, on the page, without registering them consciously but neatly enough to be able to feel the various motifs, variations and repetitions interwoven in the novel: "In a sense it was written like painting. I frequently meet people who say: 'When I reread The Famished Road, certain things that I thought I saw on certain pages, when I went back, were not there. What's happened to them?' We read contingently as well as sequentially. I was playing with this and other curious techniques a great deal in that text" (Guignery Homelands, 21). As Guignery noted when analyzing the system of echoes in the novel, "[t]his process also reflects the creative dimension of intertextuality (or here, intratextuality or autotextuality), in which repetition with variation is not mere imitation or tautology but a meaningful appropriation. In addition, the repetitions weave intricate links within a novel that has been noted for its lack of pattern" (Seeing 88). But the repetitions, as shown before, are not mere reiterations, they are more like variations on a theme, and in spite of the apparently repetitive aspect of the book there is a linearity and an evolution in it. This confirms the idea that The Famished Road can be read as Okri's family romance. Family, as previously noted, stands at the intersection between the collective and the individual, 
but also between sameness and difference. The choice of a form that seems repetitive but, when read closely, introduces elements of difference, is an apt form for a family romance, the story of an individual who gradually and simultaneously learns to become himself and to find his place in a genealogy.

The Famished Road combines Okri's various influences; hence it is writing characterized by a "syncretism between the natural and supernatural, traditional and modern, realist and non-realist, which deconstructs these oppositions, showing them to be interpenetrating and interdependent" (Gaylard 98). Fernandez Vasquez attributes this duality to Okri's various literary forebears in the Nigerian tradition:

The narrative technique that Okri deploys in The Famished Road could be described as a synthesis of the two main aesthetic tendencies in postcolonial African literature; the down-to-earth style practised by Chinua Achebe and the mythic writing developed by Amos Tutola and D. O. Fagunwa. $(88)^{4}$

He also explains that the novel combines Western and African influences, and that "the way in which Okri bends the Bildungsroman until it bears the burden of the African experience is itself a good example of how alien devices can be successfully incorporated into a domestic framework" (101). The Famished Road is therefore a haunted text; ${ }^{5}$ this haunting process acquires a fruitful dimension and literally becomes a "hauntology," in the Derridean sense of the term, which implies that "being" also means "being haunted." The Famished Road is haunted by Okri's literary predecessors, as suggested by Cooper's assertion that " $[\mathrm{o}] \mathrm{n}$ the one hand he opposes the slavish imitation of Western forms and ideas. This gives rise to the search for a pure, pre-colonial past, linked to projects of national reconstruction. On the other hand there is his love of change and celebration of the transformations arising out of interactions with other cultures" (74). ${ }^{7}$ Okri gives birth to an abiku character whose spectral dimension is subverted and turned into a celebration of life and literature. The book thus becomes both the abiku novel appropriate for writing about an "abiku nation" (567) and Okri's literary family romance, invoking literary parents as diverse as Homer, Tutuola or Achebe, a "polyglot family tree" reminiscent of Rushdie's conception of literary affiliation:

But we are inescapably international writers at a time when the novel has never been a more international form [...] and it is perhaps one of the more pleasant freedoms of the literary migrant to be able to choose his parents. My own - selected half consciously, half

4. Also see Pietro Deandra's synthesis concerning the abiku and its various literary avatars (in particular 48-9).

5. Costantini analyses Azaro as a character "haunted by presences," but she sees this haunting as a "psychological burden" that oppresses him (204).

6. 'Therefore 'I am' would mean 'I am haunted': I am haunted by myself who am (haunted by myself who am haunted by myself who am....and so forth). Wherever there is Ego, ES SPUKT, 'it spooks' (...not simply 'it spooks', as we have just ventured to translate, but 'it returns', 'it ghosts', 'it specters'). The essential mode of self-presence of the cogito would be the haunting obsession of this "ES SPUKT"' (Derrida 166).

7. Wright also insists on the dual position of Western African writers resorting to "magic history" in their novels, "with the result that this school of writing, even where it has intensified around specifically African concepts of identity, has at the same time broadened links with world literature and international culture. The areas of these fictions where Western postmodernism and African postcolonialism most closely converge are the problematic relations between history and fiction and techniques of character construction" (183). This notion is contested by Deandra, who considers applying the "postmodern" label to Okri's abiku novels as a form of "uprooting" that negates the fact that these novels "are solidly rooted in their Nigerian socio-historical context" (59). Costantini also terms the label "reductive" because "though it accounts for some formal aspects of his writing, it is at odds with his ideological stance" (18): "Okri uses postmodern strategies to denounce the chaos of modernity, but he simultaneously articulates a discourse on art and history that is meant to disclose a deeper and truer reality" (20). She agrees, however, on Okri's hybridity and capacity to graft "Western tropes onto this [African] tradition" (207). 
not - include Gogol, Cervantes, Kafka, Melville, Machado de Assis; a polyglot family tree, against which I measure myself, and to which I would be honoured to belong. (21)

In the end, the emphasis on repeated rebirths in the novel as well as the pre-eminence of metamorphosis and shape-shifting linked with Okri's fluid conception of identity, result in a book in which the writer constantly reinvents himself and becomes, in a way, the son of one his characters, Dad, "redreaming the world" and redreaming the novel.

The Famished Road thus ultimately appears as a novel of origins. Dad's assertion that "[m] any people reside in us" (573) defines it, echoing Okri's description of "the conception of consciousness that emerges in the book [...] which is already aware of other lives behind it and in front and also of people actually living their futures in the present" (Wilkinson 83). Many texts underlie The Famished Road, echoing, reverberating, being combined in new ways and turned into something unfamiliar, yet deeply exhilarating. Perhaps Okri's conception of identity, both literary and personal, can be described as genealogical, that is, including both what precedes and what follows it, combining cyclicality and linearity, identity and otherness. Okri's hybrid family romance probably offers the best analysis of its form in the recurring scenes involving "mutant customers" (157) in Madame Koto's bar, in which the strange people are always both familiar and different, like Okri's own writing.

Mélanie Joseph-VILAIN Université de Bourgogne

\section{Works Cited}

BeLlemin-NoËL, Jean. "Les romans familiaux d'Angélique (Le Rêve de Zola)." Le Roman familial. Groupe de recherches sur la critique littéraire et les sciences humaines de Pau. Pau: Université de Pau et des Pays de l'Adour, coll. des Cahiers de l'université, 1985. 35-55.

Costantini, Mariaconceta. Bebind the Mask: A Study of Ben Okris Fiction. Roma: Carocci, 2002.

DeAndRA, Pietro. Fertile Crossings: Metamorphoses of Genre in Anglophone West African Literature. Amsterdam: Rodopi, 2002.

Derrida, Jacques. Specters of Marx. 1994. Trans. Peggy Kamuf. New York: Routledge Classics, 2006.

Fernandez VAsquez, José Santiago. "Recharting the Geography of Genre: Ben Okri's The Famished Road as a Postcolonial Bildungsroman." Journal of Commonwealth Literature 37.2 (2002): 85-107.

Freud, Sigmund. "Family Romances." 1909. The Standard Edition of the Complete Psychological Works of Sigmund Freud. Volume IX (1906-1908): Jensen's 'Gradiva' and Other Works. Ed. J. STRACHEY. London: Hogarth Press, 1950. 235-42.

GAYLARD Gerald. After Colonialism: African Postmodernism and Magical Realism. Johannesburg: Witts UP, 2005.

Guignery, Vanessa. Seeing and Being: Ben Okri's The Famished Road. Paris: PUF/CNED, 2012.

-. The Famished Road: Ben Okri's Imaginary Homelands. Newcastle-upon-Tyne: Cambridge Scholars Press, 2013.

Hattersley, Roy. "Ben Okri: A Man in Two Minds.” The Guardian 21 August 1999: 6.

Hawley, John C. "Ben Okri's Spirit Child: Abiku Migration and Postmodernity." Research in African Literatures 26.1 (Spring 1995): 30-9.

HilenaAr, Henk. "Marthe Robert, the Family Romance and Ourselves." Fathers and Mothers in Literature. Ed. Henk HilenaAR, and Walter SCHÖNAu. Amsterdam: Rodopi, 1994. 1-6.

JarRY, André. "Instance maternelle, instance paternelle dans l'œuvre d'Alfred de Vigny." Fathers and Mothers in Literature. In HiLENAAR and SCHÖNAU, 155-68.

Linguanti, Elsa. "Introduction." Coterminous Worlds: Magical Realism and Contemporary Post-Colonial Literature in English. Ed. Elsa Linguanti, Francesco CasotTi, and Carmen Concilio. Amsterdam: Rodopi, 1999. 1-7.

Mujolla-Mellor, Sophie. "Family Romance." International Dictionary of Psychoanalysis. Ed. Alain DE Mijolda. Detroit: Macmillan Reference USA, 2005. 548-9. 
Okri, Ben. The Famished Road. 1991. London: Vintage, 2003.

Oliva, Renato. "Redreaming the World: Ben Okri's Shamanic Realism.” In Linguanti et al., 171-96.

Phillips, Maggi. "Ben Okri's River Narratives: The Famished Road and Songs of Enchantment." Contemporary African Fiction. Ed. Derek Wright. Bayreuth: Bayreuth African Studies 42, 1997.167-79.

QuAYson, Ato. Strategic Transformations in Nigerian Writing: Orality and History in the Work of Rev. Samuel Johnson, Amos Tutuola, Wole Soyinka and Ben Okri. Oxford: Bloomington \& Indianapolis: James Currey / Indiana UP, 1997.

Quayson, Ato. "Protocols of Representation and the Problem of Constituting an African 'Gnosis': Achebe and Okri." The Yearbook of English Studies 27 (1997): 137-49.

RoBert, Marthe. Roman des origines et origines du roman. Paris: Gallimard, 1972.

RusHDiE, Salman. Imaginary Homelands. London: Granta Books, 1991.

Wilce, Hilary. "My Best Teacher: An Interview with Ben Okri." Times Educational Supplement n 4396 (29 September 2000): 7.

Wilkinson, Jane. "Ben Okri." Talking with African Writers. London and Porstmouth (NH): James Currey and Heinemann, 1992. 76-89.

Wright, Derek. "Postmodernism as Realism: Magic History in Recent West African Fiction." Contemporary African Fiction. Ed. Derek Wright. Bayreuth: Bayreuth African Studies 42, 1997. 181 207. 